\title{
超高精細撮像装置における斜め画素ずらしの検討
}

\author{
正会員 三 谷 公 二十正会員 藤 田 欣 裕 $^{\dagger}$, 正会員 島 本 洋 ${ }^{\dagger}$
}

\section{A Study of Spatial Offset Method in the Diagonal Direction for a Very High Resolution Pickup System}

\author{
Kohji Mitani $^{\dagger}$, Yoshihiro Fujita ${ }^{\dagger}$ and Hiroshi Shimamoto ${ }^{\dagger}$
}

\begin{abstract}
An experimental 2,000-line image pick-up system using the four-imager pick-up method is studied with the aim of developing an ultrahigh-definition image pick-up system that surpasses a highdefinition system. Using existing high-definition pick-up elements and lenses, a 2,000-line image pick-up experimental system with improved vertical resolution has already been developed In this development, the pixels are offset diagonally between the image pick-up elements of two imagers to make the fourimager pick-up method used to improve resolution even more efficient. In addition, a technique where by spatial sample points are taken to be quincunx samples is studied in an effort to improve horizontal and vertical resolution.

In this paper, we report on our investigations into achieving greater horizontal and vertical resolution by offsetting pixels diagonally using HDTV 2/3-inch 2M-pixel charge modulation devices (CMD) We also report on our success in achieving both a horizontal and vertical limiting resolution of more than $1300 \mathrm{TVL}$ through image pick-up testing

In regard to the approach used to achieve ultrahigh-definition through the multi-imager method, comparisons were made between two-imager pixel offset high definition and simple multi-pixel high definition. We verified that there was no deterioration in $\mathrm{S} / \mathrm{N}$ and sensitivity, and that there was a gain in dynamic range In addition, simulation showed a limitation resolution curve that included errors in the mounting position of the prisms for the two-imager pick-up elements. The relation between the limiting resolution point and mounting precision is also studied.
\end{abstract}

\section{1. ま え がき}

近年, ネットワークの発達, およびパーソナルコン ピュータの普及を背景とした将来のディジタル社会に おける大容量情報伝達媒体のひとつとして, 超高解像 度映像システムが提案され1), 基礎技術の検討や電子 新聞, 遠隔医療などへの応用の検討が行われ始めた.

一方, 我々は番組制作の観点から, 超高精細映像が
NTSC ハイビジョンなど既存メディアの映像効果 をより多彩にするものと考え, 従来の 3 板撮像方式と は異なる 4 板撮像方式を提案し2)，2000 ライン撮像実 験装置の検討を行ってきた ${ }^{3)}$ 。この 2000 ライン撮像 実験装置は, 八イビジョンを超える超高精細撮像装置 の開発をめざし，その第一段階として既存のハイビジ ヨン撮像素子およびレンズを用い, 垂直方向への高精 細化を図ったものである。ハイビジョン用 $2 / 3$ インチ

キーワード：超高精細撮像装置，4板撮像方式， 200 万画素 CMD，画素ずらし

$\dagger$ NHK 放送技術研究所 ( 157 東京都世田谷区砧 1-10-11, TEL 03-5494-2312)

$\dagger$ NHK Science and Technical Research Laboratories (1-10-11, Kınuta, Setagaya-ku, Tokyo 157, Japan) 
200 万画素 Charge Modulation Device (以下 CMD と記す) ${ }^{4)}$ 撮像素子を用い, 緑 $(\mathrm{G})$ 信号用に用いる 2 枚の撮像素子の間で垂直方向に画素ずらしを行うこと により, G 信号に抢いて垂直解像度 $1800 \mathrm{TV}$ 本を達 成した。

ここで用いた 4 板撮像方式は，1台の撮像装置に使 用する撮像素子の枚数を増やし, 撮像素子間に空間画 素ずらし法を導入することによって高解像度映像を得 る方法である。このような多板化によるアプローチ は，1枚の撮像素子内での多画素化による高解像度法 に比べ画素サイズの大きい撮像素子を用いることがで きるため, 単体素子としては感度, $S / N$, ダイナミッ クレンジなど, 基本撮像特性の良い撮像素子を用いる ことができる. 反面，2つの撮像素子の出力信号合成 によるノイズの増加, 画素ずらしの際の 2 つの撮像素 子の開口重なり，および画素ずらし位置の誤差による 高域周波数特性の低下など, 検討課題も多い.

本論文では, 超高精細撮像実現へ向け, 4 板撮像方 式を用いてょり効果的に高解像度化を図るため, $2 つ$ の 200 万画素撮像素子を用いて斜め方向への画素ずら しにより空間サンプル点を五の目配置とし，水平・垂 直両方向へ高解像度化する方法を検討した。まず，超 高精細映像を得る方法として，画素ずらしを用いた多 板方式と 1 枚の撮像素子の画素数を増やす多画素方式 を $S / N$, 感度およびダイナミックレンジの点から比 較した。さらに，多板方式を用いた超高精細撮像にお いて, 解像度向上効果を大きく左右する画素ずらし位 置について位置誤差と解像度の関係を明らかにした。 また，実際に $2 / 3$ インチ 200 万画素 CMD 撮像素子を 用いて撮像実験を行い，水平・垂直方向に解像度改善 効果を確認した。

\section{2. 多画素化撮像方式と多板化撮像方式の比較}

まず，基本的な撮像素子モデルを用い，多画素化， および多板化撮像方式による単位画素あたりの信号電 荷およびノイズ電荷について比較する. Charge Cou-

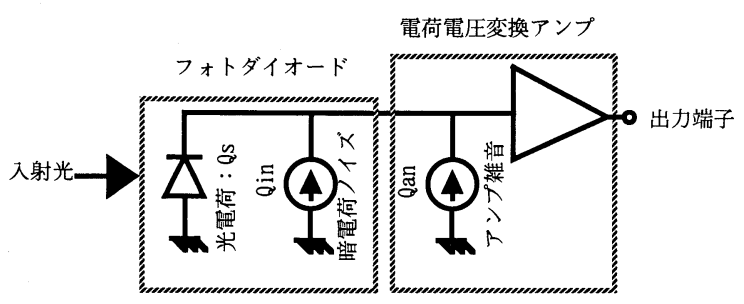

図 1 撮像素子の簡単な等価回路モデル Simple model of an image sensor. pled Device（CCD）を想定した撮像素子の基本的な モデルを図 1 に示す。撮像素子を光電変換部と出力ア ンプ部に分け, 光電変換部は入射光に応じた光電荷信 号 $Q_{s}$ を生成し, 出カアンプ部は電荷信号を電圧信号 に変換し出力する機能を持つものとした．また，発生 する付加ノイズとしては暗電流に起因したノイズ $Q_{i n}$, およびリセットノイズなどアンプ部で発生する ノイズ $Q_{a n}$ を考える. 図 2 にこの撮像素子モデルを 基にした，多板方式の最も単純な場合としての 2 板方 式による画素ずらし撮像モデル (a)，および画素面積 を半分にし, 多画素化した撮像素子の回路モデル (b) を示す. 光電荷信号量は, 入射光学像をプリズムで 2 つに分解する多板方式 (a) と, 画素単位面積が半分と なる多画素方式 $(\mathrm{b})$ とも, 基準モデルの半分となる. また，アンプノイズ電荷量に関しては，多板方式の信 号合成回路において 2 つの素子出力が理想的に切り替 えられ，付加的なノイズは加わらないものと仮定する と, 単位画素あたりのノイズ量は両方式とも基準モデ ルと変わらない. 両方式で大きな差が生じるのは暗電 流によるノイズである. 多画素方式 (b) は, 単位画素 面積が小さくなるため暗電荷量が減少し, 暗電荷に起 因したノイズは基準モデルの $1 / \sqrt{2}$ となる。一方, 多板方式 (a)では, 単位画素面積は基準モデルと変わ らないため暗電荷によるノイズ量も変わらない。つま

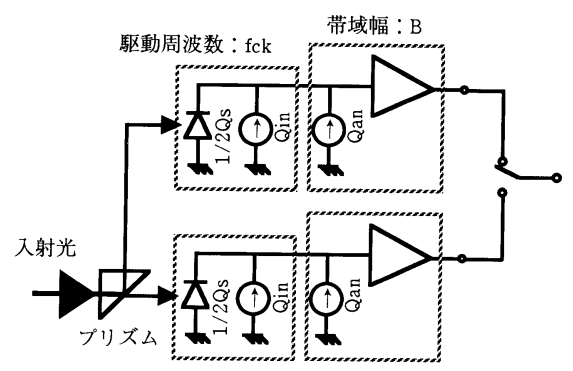

(a) 多板化撮像法

( 2 板画素ずらし)

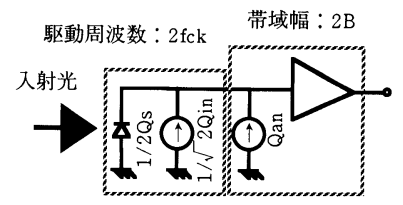

(b) 多画素化撮像法 (画素数 2 倍)

図 2 高解像度撮像における多板化撮像法と多画素化 撮像法の単位画素あたりのノイズ量の比較

The theoretical noise comparison between the multi-imager pickup method using spatial offset between the imagers and the pickup method using a gigh resolution imager. 
り, 撮像素子において暗電荷に起因したノイズが支配 的であれば, 多板化 ( 2 板化)による高精細化は多画素 化方式に比べ, $S / N$ が最大 $3 \mathrm{~dB}$ 低下寸る。しかし， 現状のハイビジョン用 200 万画素 CCD においては, 相関 2 重サンプル回路などを用いてアンプノイズを抑 圧しても，出力信号に扔けるノイズ成分はアンプノイ ズが支配的であり ${ }^{5)}$, 暗電荷に起因したノイズはほぼ 無視できる。ささに, 上記の検討は素子温度が変わら ないという条件の下で成り立ち, 実際には多画素方式 の方が素子の駆動周波数が高く素子の温度上昇により 暗電荷が発生しやすくなるため, 両方式の差は縮小す る傾向にある。またノイズの見え方について比較すれ ば，2 板方式の方が素子単体出力においてノイズの粒 が大きい.しかし，理想的な切り替え回路によって多 画素方式と同等なものとなると考えられる. 以上の結 果より, 多画素方式と多板方式により得られる出力信 号の $S / N$ は現状では同等であると考えられる.

次に，他の撮像特性として感度，ダイナミックレン ジを考える．感度に関しては多板方式で用いるプリズ ムでの光損失がなく，また多画素方式での画素縮小に よる開口率劣化がなければ, 先述したように単位画素 から同量の光信号が得られるため, 両方式ともほぼ同 等の感度であると推定できる.

一方, ダイナミックレンジに関しては，入射光をプ リズムで分解し, 画素面積の大きい撮像素子で受光す る多板方式の方が有利である. 図 2 に示す素子モデル で比較した場合, 単位画素の飽和電荷量が単位画素面 積に比例すると仮定すると, (a )の方が ( b ) に比べ飽 和入射光量は 2 倍大きくなる。

上記の検討より，画素面積が小さく，多画素化する と基本撮像特性を維持できなくなるような超高精細撮 像の領域では, 多板方式が適していると考えられる. ただし, 多板方式では撮像素子間での画素ずらし誤 差, および開口重なりにより出力される映像出力の高 域周波数応答が低下する可能性がある.
以下では, 斜め画素ずらしにより 2000 ライン撮像 装置を高解像度化する際の, 画素ずらし精度による解 像度特性への影響について検討した。

\section{3. 斜め画素ずらしにおける解像度特性の検討}

空間サンプル点を五の目配置とする方法は水平・垂 直方向の解像度が斜め方向の解像度に対し敏感な人間 の視覚特性 ${ }^{6}$ に適する方法として, ディジタル信号処 理においてもよく用いられている7).

画素ずらしを用いて五の目サンプルを実現しようと した場合, ディジタル信号処理の場合と異なる点がい くつかある、ひとつは, プリズムに固着する撮像素子 の位置誤差により五の目サンプルパターンが多少変形 する点である．特に画素ピッチが極めて狭くなる超高 精細撮像の領域では, 微小な位置合わせ誤差が画素ず らし効果に大きく影響する．ふたつめは五の目サンプ ルを行う入力信号, つまり光学像に対し充分なプリフ イル夕処理を行うことができない点である。また, 出 力信号の $S / N$ とも関係するが, 最近の撮像素子の画 素に扔ける開口率はマイクロレンズ技術により大きく 向上しており，画素ずらしを行った場合，2つの撮像 素子間で開口が重なり合い, 高域の変調度が低下する 可能性がある.

そこで，まず光学系の特性モデルを用い，理想位置 からの誤差による解像度特性劣化を検討し, 充分な性 能を実現するための素子の貼り合わせ精度について述 べる. 次に, 光学系に光学ローパスフィルタ（以下， 光学 LPF と記す）を挿入し入射光にプリフィル夕処 理を行ったときの解像度特性の変化をシミュレーショ ンする。

\section{1 レンズおよび画素の開ロモデルとその周波数 特性}

画素のモデルとして図 3 に示すような光学アパーチ ヤ特性を持つ画素を用いる。この画素はオンチップレ ンズアレイによるアパーチャ特性を考慮し，面積開口
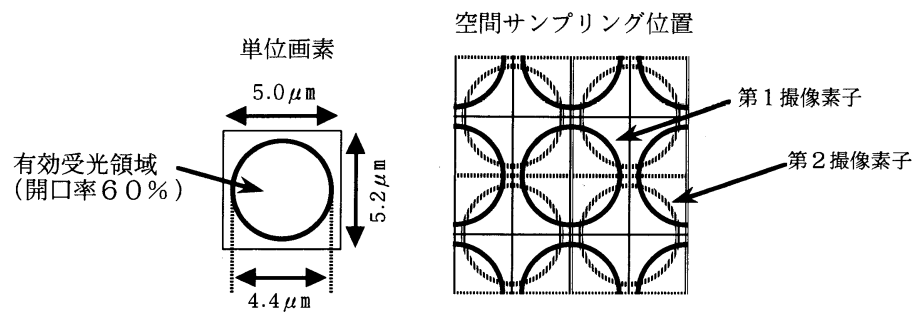

図 3 正方画素配列構造を持つ 2 枚の撮像素子を斜め方向に空間画素ずらしした時の 光学像に対する空間サンプリング位置

The spatial sampling point using the spatial offset method between two imagers in the diagonal direction. 


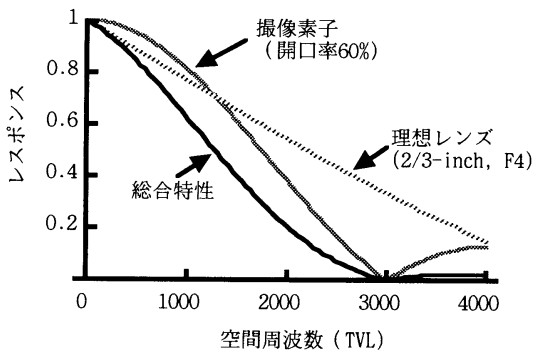

( a ) 光学系の空間周波数特性例

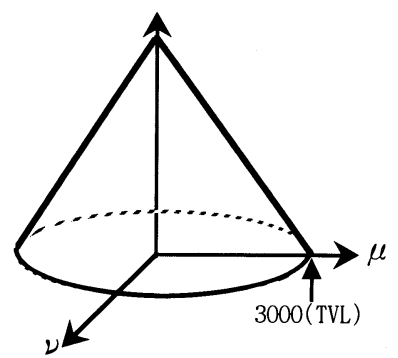

（b）２次元周波数特性モデル

図 4 超高精細カメラによる光学系の空間周波数特性, およびその 2 次元周波数特性モデル An example of spatial frequency response of optical system in the ultra high resolution pickup system and the model of the $2 \mathrm{D}$ spatial frequency response.

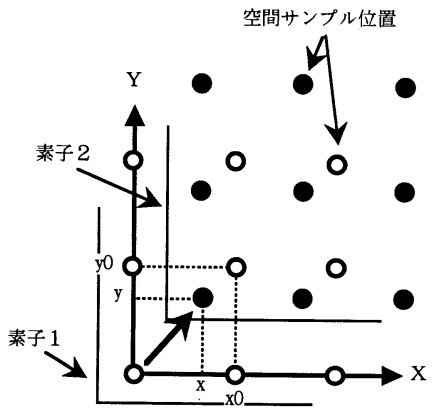

(a) 画素ずらし位置

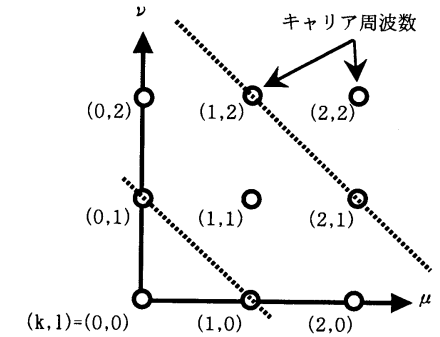

（b） キャリヤ配置

図 52 次元空間における画素ずらしモデル，およびその 2 次元周波数平面におけるキャリヤ配置 The calculation model of the spatial offset imaging method on the image plane.

率が $60 \%$ となる円形のアパーチャ特性を持つものと する．この円形アパーチャの周波数特性, および $2 / 3$ インチ，F４の理想レンズにおける周波数特性，およ びそれらの総合特性を図 $4(\mathrm{a})$ に示す．図より，約 $3000 \mathrm{TV}$ 本でその応答がヌルとなり，それ以上の周 波数成分はほとんど現れないことがわかる。また，変 調度の低下は周波数に対しほぼ直線近似できる。よっ て以下の解析ではレンズおよび画素開口特性の総合特 性として, 図 4(b) に示す円錐特性で近似した 2 次元 周波数特性を用いた。

\section{2 画素ずらし誤差による解像度特性劣化}

$X$ 軸方向に $x_{0}$ ピッチ, $Y$ 軸方向に $y_{0}$ ピッチで配 置された正方画素配列構造を持つ 2 枚の撮像素子の相 対的な撮像位置を図 5 ( a ) のように $(x, y)$ だけずらし た場合, 2 次元周波数平面 $(\mu, \nu)$ 上でのキャリアの配 置はそれぞれの素子のサンプリング位置のフーリエ変 換を加算したものとなり，次式のように表される.

$$
\begin{aligned}
F(\mu, \nu)= & \frac{1}{x_{0} y_{0}} \sum_{k} \sum_{l} \delta\left(\mu-\frac{k}{x_{0}}, \nu-\frac{l}{y_{0}}\right) \\
& \cdot\left\{1+e^{\left(-2 \pi j\left(\frac{k x}{x_{0}}+\frac{l y}{y_{0}}\right)\right)}\right\}
\end{aligned}
$$

このときの各々のキャリヤの配置は図 5(b) のよう になり，各キャリヤの振幅レベルは (1) 式の第 2 成分 で表される. 光学像が入射すると, これらのキャリヤ 成分を中心に入射信号成分が 2 次元空間周波数面上に 広がる. 2 枚の撮像素子の相対位置が斜め方向へ正確 に $(x, y)=(2.5 \mu \mathrm{m}, 2.6 \mu \mathrm{m})$ だけずれている場合に は, 図 5(b) の点線で示された線上に存在するキャリ ヤ成分は抑圧され, ベースバンド帯域内への折り返し が抑圧され高域解像度が改善される。つまり，画素ず らしで得られる出力信号の解像度特性は, 周囲のキャ リヤ成分による折り返し成分の合成電力とベースバン ド帯域内の電力で決定される。実際には帯域内の変調 度特性も考慮する必要があるので, ベースバンド成分 と折り返し成分の電力比とモニ夕上で観測される限界 


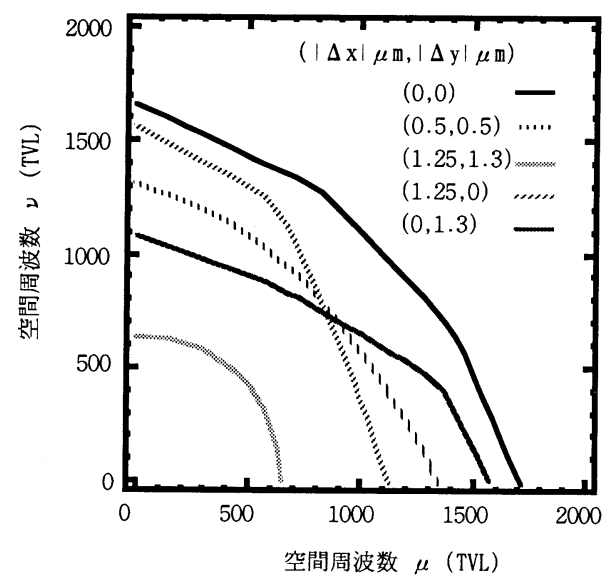

図 6 画素ずらし誤差による限界解像曲線の変化 The relationship between the accuracy of the offset position and the limiting resolution in the image offsetting method.

解像度とを直接関係づけることは容易ではない。しか し, ナイキスト限界などのように信号成分と折り返し 成分の量が一致する点を解像度限界点のひとつの目安 とし, 解像度特性を評価することは可能である。ここ では, 周囲のキャリヤによる折り返し成分とべースバ ンド成分が等しくなる点を限界解像点と仮定し, 2 枚 の素子の相対的位置の理想画素ずらし位置 $((x, y)=$ $(2.5 \mu \mathrm{m}, 2.6 \mu \mathrm{m}))$ からのずれ $(\Delta x, \Delta y)$ により限界解 像点がどのように変化するかを図示した（図6). 画 素ずらしが理想的に行われている $((\Delta x, \Delta y)=(0,0))$ 場合, 水平・垂直の限界解像点は約 $1700 \mathrm{TV}$ 本とな る. しかし, 画素ずらしの位置が理想的な位置から水 平・垂直方向にずれた場合には, それぞれの方向に対 する解像度が劣化していることがわかる，この図よ り, 貼り合わせ誤差が $\pm 0.5 \mu \mathrm{m}$ 以内であれば, 水 平・垂直両方向の限界解像度は $1300 \mathrm{TV}$ 本以上を達 成できることがわかる，また，理想的なサンプル位置 でも限界解像点は約 $1700 \mathrm{TV}$ 本しか達成されない原 因は, 入射光学像の周波数特性が図 4 (b) に示す円錐 形特性であるため, キャリヤ $(1,1)$ により折り返し成 分がベースバンド内に達し水平・垂直方向の解像度を 低下させているためである.そこで次に, 光学 LPF によりプリフィルタを設けた場合について検討する。

\section{3 光学 LPF の効果}

光学系内に斜め方向に効果を持つ光学 LPF を挿入 し, ベースバンド内に折り返す光学像の斜め方向成分 を抑圧することにより, 限界解像度特性を改善するこ とを考える. 斜め方向のナイキスト周波数の 1.5 倍の 周波数応答がヌルとなるコサイン特性を持つ光学

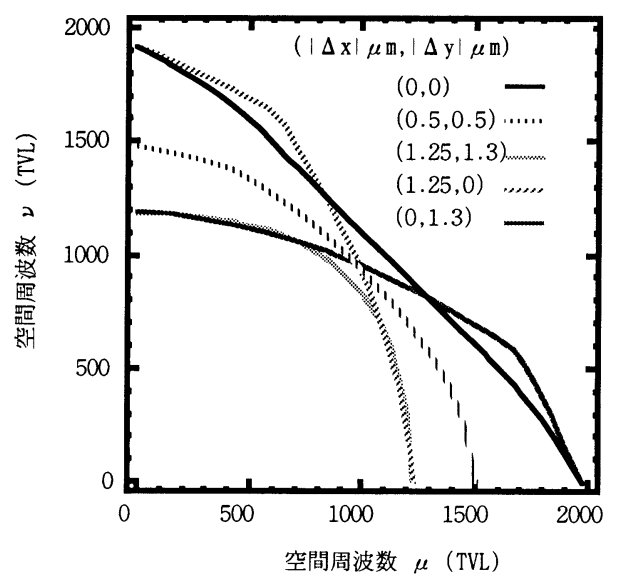

図 7 光学ローパスフィルタを用いたときの画素ずら し誤差による限界解像曲線の変化

The relationship between the accuracy of the offset position and the limiting resolution in the image offsetting method with optical low-pass filter.

LPF 2 枚挿入し, 先ほどと同様に限界解像点の算 出を行う．画素ずらし誤差による限界解像点の変化を 図 7 に示す. 光学 LPF を挿入することでベースバン ド帯域内に混入する折り返し成分は減少し，位置誤差 がない場合には, 水平・垂直方向の限界解像点は約 $2000 \mathrm{TV}$ 本に達する。また，貼り合わせ誤差を \pm 0.5 $\mu \mathrm{m}$ 以内に抑えれば, 限界解像点は $1500 \mathrm{TV}$ 本以上 を達成できる，ただし，光学 LPFを用いた場合に は, そのコサイン特性のため帯域内の変調度も低下す る. 例えば，貼り合わせ誤差のない場合の水平・垂直 方向の $1500 \mathrm{TV}$ 本に扔ける変調度は, 光学 $\mathrm{LPF}$ を用 いない場合に比べ約半分となる。この変調度低下は, 輪郭補償回路などを用い水平・垂直方向の高域周波数 特性を持ち上げることにより電気的に補正することが できる。また，補間合成によっても変調度の低下が考 えられるが，これも同様に補正が可能である。しかし ながら, 実際に輪郭補償を行う場合には $S / N$ の劣化 を考慮する必要がある。

\section{4. 撮 像 実 験}

\section{1 実験装置の仕様}

上述の検討を基に実際に撮像実験を行った。本実験 装置の仕様を表 1 に示す. 基本クロックは将来ハイビ ジョンへの切り出しを考慮し, ハイビジョンの基本周 波数の $74.25 \mathrm{MHz}$ の 4 倍の $297 \mathrm{MHz}$ とした。また， 撮像素子は順次走查可能な $2 / 3$ インチ 200 万画素 $(1920(\mathrm{H}) \times 1035(\mathrm{~V})) \mathrm{CMD}$ 撮像素子を 2 枚用いた。 2 線続み構成の $\mathrm{CMD}$ 撮像素子の水平シフトレジスタ を $74.25 \mathrm{MHz}$ で駆動することにより，1枚の撮像素 
子から 1000 ライン順次走查，60フレーム/秒の映像 信号を得ている.さらに，斜め方向に画素ずらしされ た 2 つの撮像素子の出力信号を補間, 合成することに より 2000 ライン化を達成している.

モニタとしては, 表示アスペクトが 1 対 1 の 2000

\section{表 1 実験装置の仕様}

Specification of the experimental pickup system.

\begin{tabular}{c|l}
\hline \hline システム & 60 フレーム/秒, 2000 ライン順次走査方式 \\
\hline 撮像方式 & 200 万画素 2 板式, 斜め画素ずらし \\
\hline & $\begin{array}{l}\text { ハイビジョン用 } 2 / 3 \text { インチ } 200 \text { 万 }(1920 \times 1035) \text { 画素 CMD } \\
\text { 䭬次走查駆動 } \\
\text { 駆動レート } 74.25 \mathrm{MHz} \times 2 \text { 線読出し }\end{array}$ \\
\hline 表示モニタ & $\begin{array}{l}2048(\mathrm{H}) \times 2048(\mathrm{~V}) \text { 画素, アスペクト比 } 1: 1 \\
\text { (実際はシャドウマスクにより水平は } 1600 \text { ドット) }\end{array}$ \\
\hline
\end{tabular}

ラインカラーモニタを用いた. 撮像素子の有効エリア のアスペクト比は 16 対 9 であるため, 撮像映像のう ち水平方向に半分の部分を切り出して表示し, 表示映 像の真円率をできるだけ 1 に近づけ，9/8 とした。

\section{2 実験装置の構成}

図 8 に実験装置の構成図を示す。レンズで集光され た光学像はハーフプリズムにより 2 つに分けられ， 2 枚の CMD 撮像素子に結像される. 本撮像実験では輸 郭補償回路を持たないので, 帯域内の変調度を高く維 持するため斜め方向の光学 LPF は用いていない. 2 枚の CMD 撮像素子の出力信号はプリアンプ直後で, $\mathrm{A} / \mathrm{D}$ 変換され, 光リンクモジュールによりディジタ ル信号処理部に伝送される.ディジタル信号処理部で は，固定パターンノイズ (FPN) 抑圧処理，合成・ 補間処理, ガンマ補正処理, および切り出し回路を通 過後, D/A 変換によりアナログ信号に変換され，モ

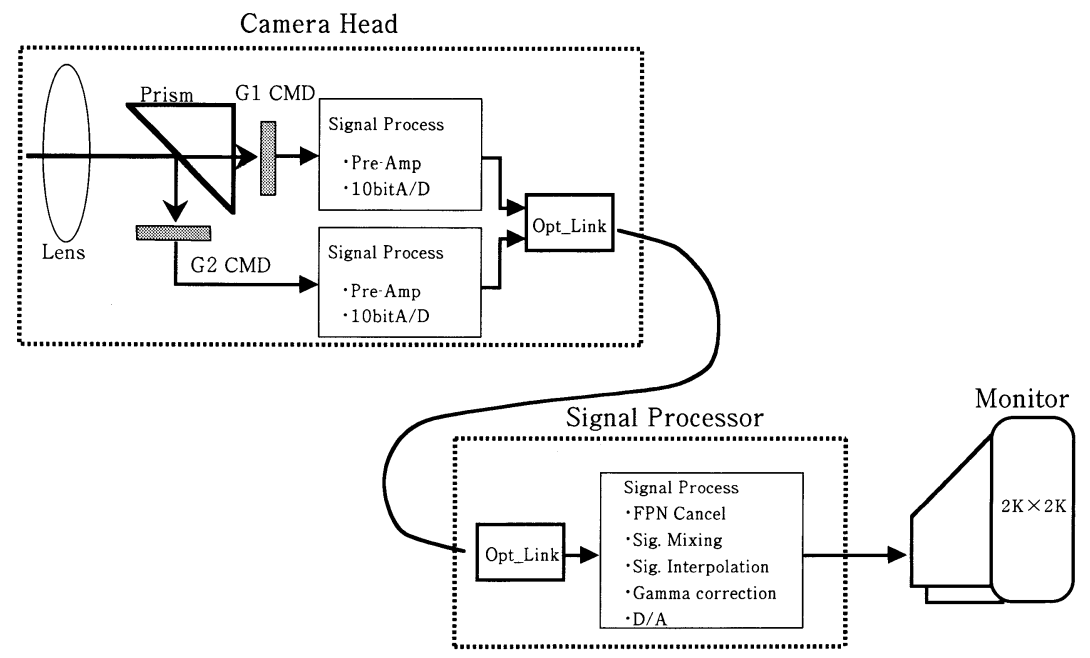

図 8 試作カメラのブロックダイヤグラム

Blockdiagram of the experimental image pickup system.

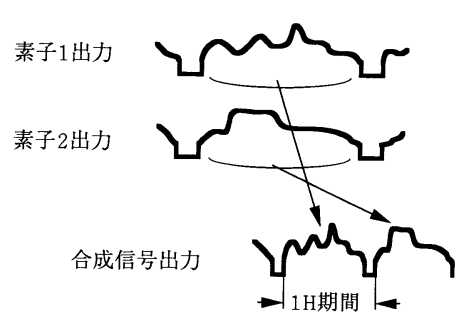

(a) 素子出力の合成

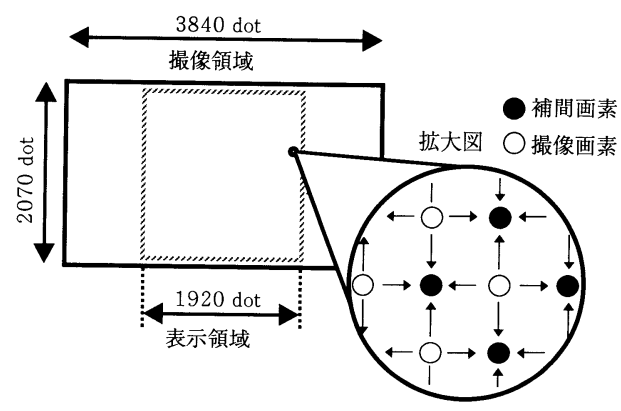

（b）表示領域の補間処理

図 9 素子出力の合成法, および画素補間法

Thd signal composing and the pixel interpolation to generate the display area data with $2 \mathrm{~K} \times 2 \mathrm{~K}$ dots. 


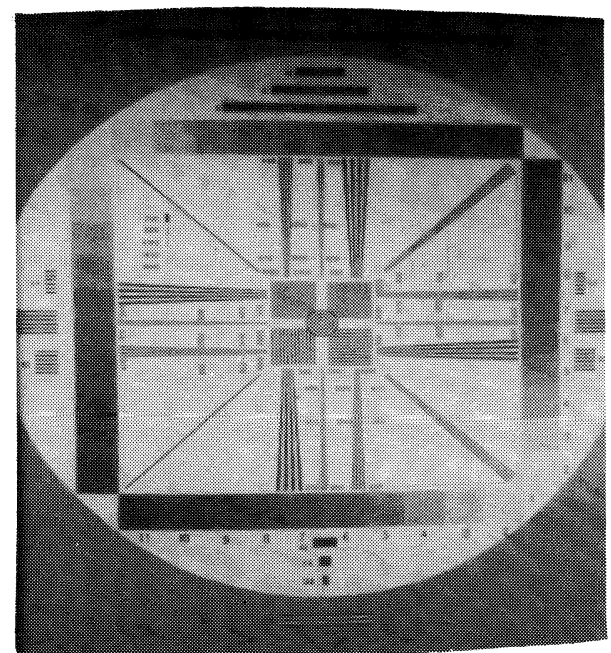

写真 1 ハイビジョン用レトマチャートの撮像例 Reproduced picture of HDTV retoma chart.

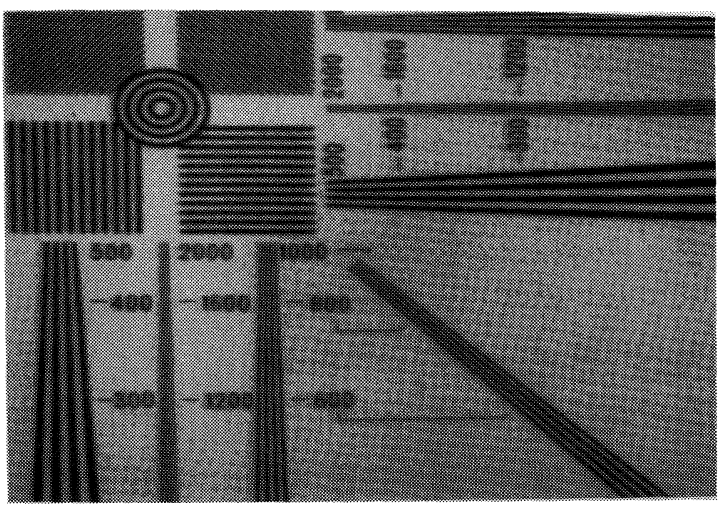

写真 2 写真 1 の中央部拡大写真 Enlarged central portion of Photo. 1

二タに出力される．信号の合成・補間処理は図 9 に示 すように, 2 つの撮像素子の出力信号を時間圧縮し, 合成するとともに, 標本点の存在しない部分のデー夕 は上下左右の画素デー夕から補間した。図 9(b) に示 すように, 全撮像データの半分の水平 1920 ドット, 垂直 2070 ラインを切り出し, モニタへ出力した. 写 真 1 にモニ夕表示画像を示す. 2000 ラインモニタで の表示画像は先に述べたように真円率は 1 とはなら ず，横方向に $9 / 8$ 倍された映像となる．写真 2 は写真 1 を拡大したものである。水平・垂直ともに限界解像 度約 $1300 \mathrm{TV}$ 本以上を達成した。上記の検討結果を 考慮すると, 素子の貼り合わせ精度が限界解像度の主 たる制約要因であると考えられる。

今後は貼り合わせ精度の向上を検討するとともに，

光学 LPF，輪郭強調回路を用い，より高解像度化を 図りたい.

\section{5.むす び}

ハイビジョン用 200 万画素撮像素子を 2 枚用い, 斜 め方向に画素ずらしを行うことにより水平・垂直両方 向への高解像度化を検討し，実際に撮像実験を行うこ とによりその効果を確認した．2板画素ずらしによる 高精細化は多画素化による高精細化に比べ， $S / N$, 感 度の点では劣化がなく, ダイナミックレンジの点では 有利であることを確認した。また，シミュレーション により 2 枚の撮像素子のプリズムへの貼り合わせ位置 に誤差が含まれる場合の限界解像曲線を示し，限界解 像度と貼り合わせ精度の関係について論じた，以上の 検討結果を基に，実際に $2 / 3$ インチ 200 万画素 CMD 撮像素子を用い，撮像実験を行い，水平・垂直方向の 限界解像度 1300 TV 本以上を達成した。

\section{〔参 考 文 献〕}

1) S. Ono, et al.: "All-Digital Super High Definition Images”, Signal Processing: Image Communication, 4 pp. 429-444 (Aug. 1992)

2）菅原ほか：“4 板撮像方式における画素ずらし効果について の検討”, テレビ誌, 49, 2, pp. 212-218（Feb. 1995）

3）三谷ほか：“4 板撮像方式を用いた 2000 ライン動画撮像実験 装置”, テレビ誌, 50, 2, pp. 295-301（Feb. 1996）

4) T. Nomoto, et al.: "A 2/3-inch 2M-Pixel CMD Image Sensor with Multi-Scanning Function”, ISSCC Digest of Technical Papers, pp. 196-197 (Feb. 1993)

5）峯ほか: “2/3 インチ 200 万画素ハイビジョン CCD カメラ”, テレビ学技報, 19, 65, pp. 25-30（Nov. 1995）

6）坂田：“テレビ雑音の見え方の周波数特性”，テレビ誌， $\mathbf{3 4}, 3$, pp. 239-245 (1980)

7) Y. Ninomiya : "MUSE Coding System for HDTV Broadcast", Trans. HD-TV Work Shop by EURASIP, 2, pp. 116 (1986)
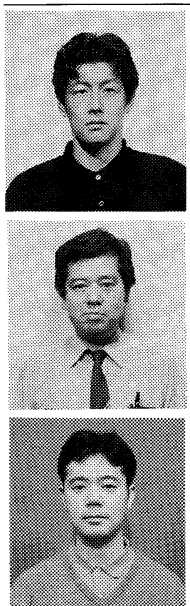

努签 公公 1987 年, 京都大学大学院修 土課程修了．同年，NHK に入局．現在，同 放送技術研究所に勤務. 画像処理, カメラシ ステムの研究に従事．正会員

藤奋欤裕 1976 年, 東京大学工学部電 気工学科卒業. 同年, NHK に入局. 大阪放 送を経て，1981年より，同放送技術研究所 に勤務し, 現在に至る. 固体撮像素子の評 価，固体力メラの研究に従事. 正会員.

島告洋 1991 年, 東京工業大学大学 院総合理工学研究科修士課程修了. 同年, NHK に入局. 金沢放送局を経て，1991年 より, 同放送技術研究所に勤務し, 現在に至 る. 固体撮像カメラの研究に従事. 正会員. 